\title{
Report of a human accident caused by Conus regius (Gastropoda, Conidae)
}

\author{
Relato de um acidente em ser humano causado por \\ Conus regius (Gastropoda, Conidae)
}

\author{
Vidal Haddad Junior ${ }^{1,2}$, Marcus Coltro ${ }^{3}$ and Luiz Ricardo L. Simone ${ }^{4}$
}

\begin{abstract}
Conus regius is a venomous mollusc in the Conidae family, which includes species responsible for severe or even fatal accidents affecting human beings. This is the first report on a clinical case involving this species. It consisted a puncture in the right hand of a diver who presented paresthesia and movement difficulty in the whole limb. The manifestations disappeared after around twelve hours, without sequelae.
\end{abstract}

Key-words: Conus regius. Poisoning. Brazil.

\section{RESUMO}

Conus regius é um molusco venenoso da família Conidae, que inclui espécies responsáveis por acidentes graves ou mesmo fatais em humanos. Os autores relatam pela primeira vez um caso clínico envolvendo a espécie, que inclui uma punctura na mão direita de um mergulhador submarino, que apresentou parestesias e dificuldade de movimentação do membro todo. 0 quadro desapareceu em cerca de doze horas, sem seqüelas.

Palavras-chaves: Conus regius. Envenenamento. Brazil.

Molluscs are common invertebrates in which the body is usually divided into a head, a visceral mass and a muscular footlike structure. Among the molluscs, the genus Conus has medical importance. This genus is the only member of the Conidae family, and it is one of the most diverse genera in the animal kingdom, with about 500 species worldwide. Their characteristic heavy conical shell is easy to identify, and their beauty attracts attention. This high diversity also brings with it high levels of adaptation, which are certainly reflected in their morphology and biochemical yields.

Gastropods of the superfamily Conoidea include predator snails. They normally prey on invertebrates like worms, polychaetes, and other molluscs. However, a few Conus species prey on fish. Since fish are vertebrates, venom that is adapted to this type of prey may be dangerous to humans.

Since the prey of Conus species is normally quicker than they are, they have developed powerful venom that can kill or instantly paralyze their prey. A special long tubular and intensely coiled gland (the venom gland) produces the venom. A muscular bulb is found at the distal end and, through intense contraction, this forces the venom to the opposite end, which is connected to the base of

1. Botucatu School of Medicine, São Paulo State University, Botucatu, SP, Brazil. 2. Vital Brasil Hospital, Butantan Institute, São Paulo, SP, Brazil. 3. Malacologist and Conchologist (Femorale Shells), São Paulo, SP, Brazil. 4. Zoology Museum of São Paulo University; PO Box 42494; ZIP 04218-970, São Paulo, SP, Brazil.

Address to: Prof. Vidal Haddad Junior. Caixa Postal 557, 18618-000 Botucatu, SP, Brazil.

Telefax: 55 14 3882-4922

e-mail: haddadjr@fmb.unesp.br

Received in 08/01/2009

Accepted in 20/07/2009 the proboscis. The proboscis is a long and muscular elongation of the oral region that is capable of substantial protrusion and exploration. The radula, which in other molluscs is just a chitinous toothed tongue used for filing down their food, is modified into the form of several hollow barbed harpoons (Figure 1). These harpoons are relatively free inside a sac, one of which is selected and directed towards the proboscis tip. They can be constantly replaced.

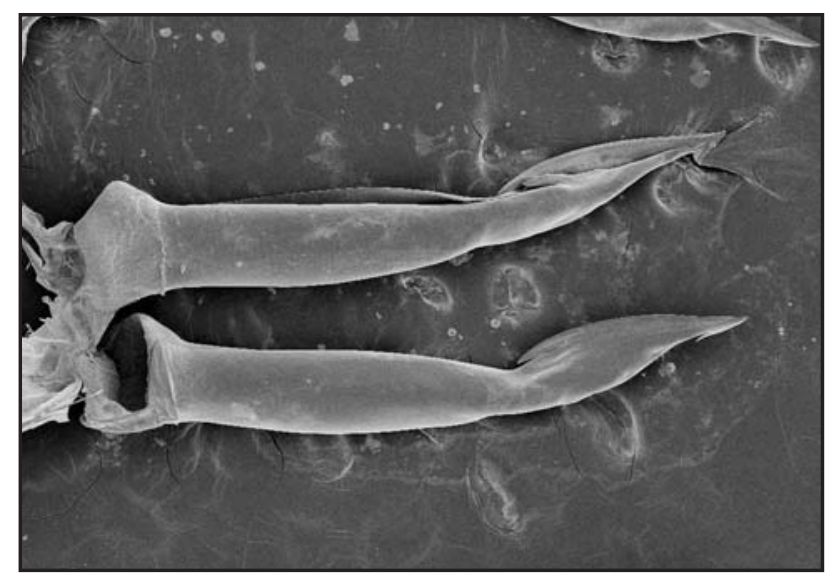

FIGURE 1

Radula apparatus of a Conus regius specimen, showing modification in the form of several barbed and hollow harpoons.

The attack mechanism is preceded by insertion of the proboscis tip harpoon into the prey. The muscular bulb contracts and the venom is propelled through the entire length of the proboscis, from the venom gland to the harpoon ${ }^{22}$. 
The venom of Conus species is composed of conotoxins, which are low molecular weight neurotoxins. The venom has two different effects. The first, the lightning-strike effect, causes immediate immobilization, and the second, which is achieved more slowly, causes complete inhibition of neuromuscular transmission $^{22} 23$. Poisoning by Conus species that feed on worms and molluscs causes mild poisoning in humans, but accidents caused by piscivorous Conus may be fatal ${ }^{714}$. During the day, they are inactive under rocks, shell fragments and coral. Once collected, they must be handled with care and should not be touched at their opening. One of the most common species in Brazil is Conus regius Gmelin, 1791, which actively feeds on marine worms ${ }^{2}$. When one specimen is collected, there are probably several in the same region, called the 'point of Conus'.

A typical accident caused by a Conus species initially shows as mild local pain and evolves to progressive muscle paralysis in about one hour, without other local signs or symptoms. A history of contact with these molluscs, associated with severe muscle weakness, raises a suspicion of such an accident. At later stages, patients may develop palpebral ptosis, blurred vision, speech and deglutition difficulty, unconsciousness and dyspnea, with possible evolution to respiratory arrest. This may be fatal and can occur between 40 minutes and five hours after the sting 3791214161819 .

There are more than 30 species of the genus Conus along the Brazilian coast ${ }^{5020}$. One is known to prey on fish: Conus ermineus Born, $1778^{146811}$. However, possibly due to its rarity and deepwater environment, no human accident with this species has so far been reported.

On the other hand, Conus regius is a very common species that occurs all the way from the Caribbean Sea down to the coast of the State of São Paulo, Brazil. It is most abundant in warm waters, especially in northeastern Brazil (Figures 2 and 3). It is a shallow-water species, and can be collected from the intertidal zone. Adult specimens range in size from about $3 \mathrm{~cm}$ on the coast of the State of Espírito Santo to more than $10 \mathrm{~cm}$ in the archipelago of Fernando de Noronha. As far as is known, Conus regius preys

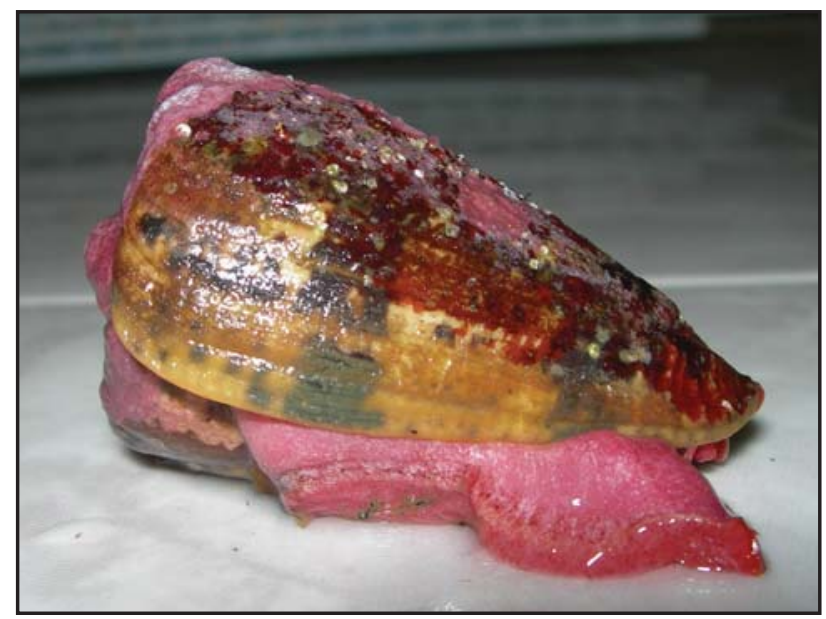

FIGURE 2

Live Conus regius specimen. This mollusc is a very common species found from the Caribbean Sea to the São Paulo coast, Brazil.

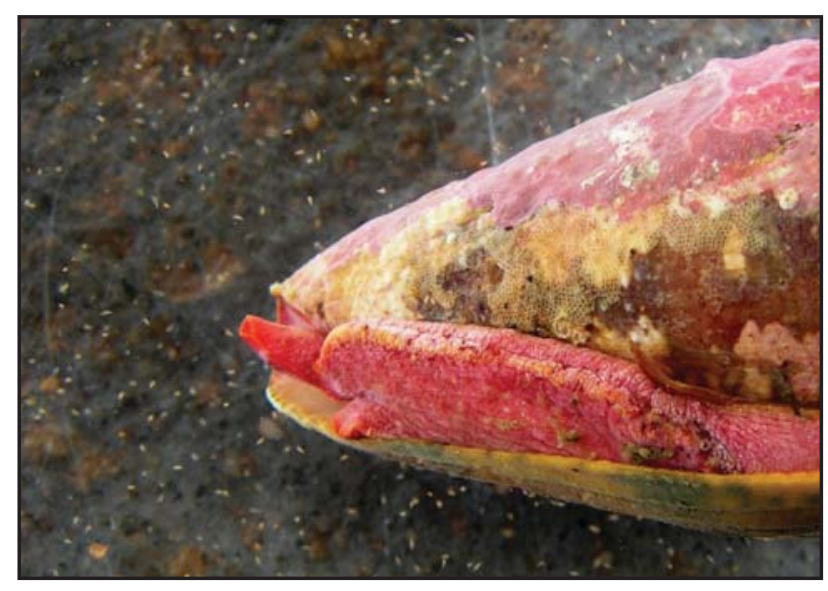

FIGURE 3

Detail of Conus regius showing the animal's body with the proboscis.

on polychaetes, which are annelid marine worms. Studies in the literature have already investigated the venom composition of this species ${ }^{2}$, revealing a complex of biologically active peptides that paralyses the prey of this species through interactions with receptors and ion channels. In addition to the well-developed venom gland, two other pairs of glands also act in the attacks. These are the salivary glands and the proboscis glands. The latter are a pair of elongated, balloon-like glands that are surrounded by the venom gland. The proboscis and venom glands are extracted together through dissection, and the proboscis gland certainly has an influence on venom action.

\section{CASE REPORT}

A 42-year-old male patient suffered an accident while scuba diving to look for shells on an intertidal rocky outcrop near Itapoan in the city of Salvador, State of Bahia, Brazil. The injury occurred around 10:00 a.m., after the victim had collected two Conus regius specimens. The patient was an experienced diver and shell collector and had no doubt about the identity of the specimens that he was handling. According to his report, he knew about the risks of handling Conus specimens in Indo-Pacific regions, having read warnings from collectors, but was unaware that the problem could also exist among Brazilian specimens. The handling procedure that the patient had been following for the specimens that he collected was to put the soft parts of the body under pressure in order to extract the operculum.

After manipulating two specimens, he noticed a very small puncture in his right hand and felt a slight itching sensation, which was followed by local tingling and numbness. These symptoms later extended to the wrist and forearm, and after a few hours, he experienced paresthesia, numbness and mild difficulty in movement in his entire upper limb. There was no sensation of pain or any systemic phenomenon such as disseminated paresthesia, perioral tingling, alteration of consciousness or muscle palsy, etc. The heavy arm feeling remained throughout the day and had disappeared by the following morning, without leaving any sequelae. 


\section{DISCUSSION}

In a previous study, Haddad Jr et al raised the possibility that accidents caused by molluscs of genus Conus could occur in Brazil $^{13}$, citing the species Conus regius as a likely potential agent. The major risk group would be composed of individuals who were collecting shells for scientific purposes and for collections. This has been confirmed by this report.

Conus regius is widely distributed along the Brazilian coast, and can be collected in almost all but the southernmost regions of the country ${ }^{20}$. Although Conus regius feeds on polychaetes, which in theory reduces the severity of accidents compared with the accidents that involve piscivorous species, there is still no real estimate of the magnitude of poisoning occurrences.

Another interesting aspect of this report was the mild gravity of the accident. It had neuromuscular effects that were not associated with systemic changes, although the action by the neurotoxic venom was evident. Populations at risk (scientific researchers, divers, etc.) need to be aware of the risks of accidents in Brazil caused by Conus regius and other Conus species.

\section{ACKNOWLEDGMENTS}

To Mr. Luiz Fernando Trinchão Pires, whose support was vital for the preparation of this manuscript.

\section{REFERENCES}

1. Barbier J, Lamthanh H, Le Gall F, Favreau P, Benoit E, Chen H, Gilles N, Ilan N, Heinemann SH, Gordon D, Menez A, Molgo J. A delta -conotoxin from Conus ermineus venom inhibits inactivation in vertebrate neuronal $\mathrm{Na}(+)$ channels, but not in skeletal and cardiac muscles. Journal of Biological Chemistry 279:4680$4685,2003$.

2. Braga MCV, Konno K, Portaro FC, Freitas JC, Yamane T, Olivera BM, Pimenta DC. Mass spectrometric and high performance liquid chromatography profiling of the venom of the Brazilian vermivorous mollusc Conus regius: feeding behavior and identification of one novel conotoxin. Toxicon 45:113-122, 2005

3. Cardoso JLC, França FOS, Wen FH, Malaque CMS, Haddad Jr V. Animais peçonhentos no Brasil: Biologia, Clínica e Terapêutica dos Acidentes. Editora Sarvier, São Paulo, 2003.

4. Chierici S, Jourdan M, Figuet M, Dumy P. Synthesis of cis-Pro isomer analogs of delta-Conotoxin EVIA from Conus erminius. A case study of 2,2-dimethylthiazolidine as locked cis proline amide bond: synthesis, NMR and molecular modeling studies of a [small delta]-conotoxin EVIA peptide analog. Organic and Molecular Biochemistry 2: 2437-2441, 2004.

5. Coltro J. New Species of Conidae from Northeastern Brazil (Conus bodarti, Conus henckesi, Conus delucai, Conus schirrmeisteri, Conus baiano, Conus cargilei, Conus mauricioi, Conus pseudocardinalis). Strombus, p.11, 2004.

6. Costa FHA. Primeiro registro de Conus ermineus Born, 1778 (Gastropoda, Conidae) para o Arquipélago de Fernando de Noronha, com alguns comentários sobre sua periculosidade para o homem. In: Anais do XII Encontro Brasileiro de Malacologia, São Paulo, p.33, 1991.

7. Cruz LJ, White J. Clinical toxicology of Conus snail stings. In: Meier J, White J (eds). Clinical Toxicology of Animal Venoms. CRC Press, Boca Raton , p.117-128, 1995.

8. Duarte L. Danger from Conus ermineus. In: Burnay LP, Montiero AA (eds) Seashells from Cape Verde Islands. Lisbon p.45, 1977.

9. Flecker H. Cone shell poisoning, with report of a fatal case. Medical Journal of Australia 1: 464-466, 1936.

10. Gomes RC. Família Conidae no Brasil. 2001. http;//www.conchasbrasil.org.br/ ata_030510.asp. Acessed in 05/10/2005.

11. Guest RR. Observations on the feeding behavior of Conus aurantius Hwass in Bruguiere, 1792 and Conus ermineus Born, 1778, collected from Bonaire, Netherlands Antilles. Veliger 19: 204-206, 1976.

12. Haddad Jr V. Animais Aquáticos Potencialmente Perigosos do Brasil: guia médico e biológico (Dangerous Aquatic Animals of Brazil: a medical and biological guide). Editora Roca, São Paulo, 2008.

13. Haddad Jr V, Paula Neto JB, Cobo VJ. Venomous molluscs: the risks of human accidents by Conus snails (Gastropoda, Conidae) in Brazil. Revista da Sociedade Brasileira de Medicina Tropical 39: 498-500, 2006.

14. Kohn AJ. Piscivorous gastropods in the genus Conus. Proceedings of the National Academy of Sciences 42:168-171, 1956.

15. Kohn AJ. Recent cases of human injury due to venomous marine snails of the genus Conus. Hawaii Medical Journal 17:528-532, 1958.

16. Mebs D. Venomous and Poisonous Animals - a Handbook for Biologists, Toxicologists and Toxinologists, Physicians and Pharmacists. Chemical Rubber Company Press, Boca Raton, 2002.

17. Miljanich GP. Ziconotide: neuronal calcium channel blocker for treating severe chronic pain. Current Medicinal Chemistry 11: 3029-3040, 2004.

18. Petrauskas LE. A case of Conus shell poisoning by "bite" in Manus Island. New Guinea Medical Journal 1:67-68, 1955.

19. Rice RD, Halstead BW. Report of a fatal cone shell sting by Conus geographus Linnaeus. Toxicon 5:223-224, 1968.

20. Rios ECR. Seashells of Brazil. Second edition. Museu Oceanográfico da Fundação Universidade Federal do Rio Grande. Rio Grande, 1994.

21. Rojas A, Fereguino A, Ibarra-Alvarado C, Aguilar MB, Falcón A, Heimer de la Cotera E. Pharmacological characterization of venoms obtained from Mexican toxoglossate gastropods on isolated guinea pig ileum. Journal of Venomous Animals and Toxins including Tropical Diseases 14: 497-513, 2008.

22. Ruppert EE, Fox RS, Barnes RD. Invertebrate Zoology, A Functional Evolutionary Approach. $7^{\text {th }}$ edition Brooks/Cole-Thomson Learning. Belmont, CA, 2003.

23. Terlau H, Olivera BM. Conus venoms: a rich source of novel ion channel-targeted peptides. Physiological Reviews 84: 41-68, 2004 